\title{
KEPUASAN PELANGGAN TOKO ONLINE YANG DIPENGARUHI KUALITAS PRODUK DAN LAYANAN
}

\author{
T. Husain'; Asrul Sani² \\ Program Studi Sistem Informasi ${ }^{1}$ Program Studi Teknik Informatika ${ }^{2}$ \\ STMIK Widuri ${ }^{1,2}$ \\ thusain0506856@gmail.com¹, asrulsani@kampuswiduri.ac.id²
}

\begin{abstract}
Online shopping is a new form of communication that does not require face-to-face meeting. If consumers get good service rights, then the added value for a company that will make consumers will continue to make transactions at that place. The trust of a customer is very important for an online company. A customer must have a positive attitude towards the online store. The method used in this research is positivistic method based on the philosophy of positivism. The data will be used in the form of numbers and analysis using statistics in order to explain the causal relationship to be examined. This research can be used as input and performance evaluation related to service quality and product quality on trust to achieve customer satisfaction in an online store.
\end{abstract}

Keywords: Satisfaction, Service, Customers, Online Stores.

Intisari- Kegiatan belanja online merupakan bentuk komunikasi baru yang tidak memerlukan tatap muka secara langsung Jika konsumen mendapatkan hak pelayanan yang baik, maka nilai tambah bagi sebuah perusahaan yang akan membuat konsumen akan terus melakukan transaksi di tempat itu. Kepercayaan dari seorang pelanggan merupakan hal yang sangat penting bagi sebuah perusahaan online. Seorang pelanggan harus mempunyai sikap yang positif terhadap toko online. Metode yang digunakan dalam penelitian ini adalah metode positivistic dengan berdasarkan filsafat positivisme. Data yang akan digunakan berupa angka dan analysis menggunakan statistik dengan tujuan untuk menjelaskan hubungan sebab akibat yang akan diteliti. Penelitan ini dapat dijadikan masukan dan evaluasi kinerja terkait kualitas pelayanan dan kualitas produk terhadap kepercyaan untuk mencapai kepuasan pelanggan pada sebuah toko online.

Kata Kunci: Kepuasan, Pelayanan, Pelanggan, Toko Online.

\section{PENDAHULUAN}

Model gaya hidup sekarang yang didukung segala kelebihan dari belanja online, menghasilkan toko online yang baru. Kegiatan belanja online merupakan bentuk komunikasi baru yang tidak memerlukan tatap muka secara langsung(Sari, 2015). Pengusaha pun banyak yang menawarkan jasa dan barang mereka secara online, tuntutan untuk mengembangkan strategi pemasaran yang tepat, salah satunya adalah meningkatkan kualitas pelayanan (Fauzi \& Harli, 2017) dan barang terhadap calon konsumen(Wiliani, Sani, \& Andyanto, 2019). Jika konsumen mendapatkan hak pelayanan yang baik, maka nilai tambah bagi sebuah perusahaan yang akan membuat konsumen akan terus melakukan transaksi di tempat itu(Widiyanto \& Prasilowati, 2015). Kepercayaan dari seorang pelanggan merupakan hal yang sangat penting bagi sebuah perusahaan online. Seorang pelanggan harus mempunyai sikap yang positif terhadap toko online. Saat ini beberapa toko online masih kurang memperhatikan kepuasan pelanggan mereka(Siahaan, Handayani, Pungkasanti, Wiliani, \& Surorejo, 2018). Kualitas pelayanan dan produk bergantung kepada upaya memuaskan keinginan dan permintaan pelanggan. Penelitian ini menggunakan variabel kualitas pelayanan dan kualitas produk dimensi, dengan menggunakan responden Z-generation(Sani, 2018), anak yang memiliki pengetahuan teknologi atau yang biasa disebut net generation. Responden yang senang melakukan interaksi dengan komputer dan berkomunikasi dengan dunia maya(Siahaan et al., 2018). Penelitan ini dapat dijadikan masukan dan evaluasi kinerja terkait kualitas pelayanan dan kualitas produk terhadap kepercyaan untuk mencapai kepuasan pelanggan pada sebuah toko online.

\section{Kualitas Pelayanan}

Kualitas adalah sebuah kata yang bagi penyedia jasa dapat berguna dengan baik memiliki mutu yang bernilai harganya. Pelayanan yang baik juga mendukung kualitas atau mutu dari perusahaan itu sendiri.

\section{Jasa}

Secara umum jasa merupakan kegiatan yang tidak berwujud, tidak dapat disimpan serta tidak 
dimiliki. Jasa merupakan aktivitas ekonomi yang ditawarkan oleh satu pihak kepada pihak lain yang akan membawa hasil.

\section{BAHAN DAN METODE}

Penelitian ini melihat hubungan sebab akibat dari pengaruh eksogen (X) terhadap variabel intervening (Y) dan variabel endogen (Z)(Wiliani, Rahman, Ramli, \& Sani, 2019). Variabel yang akan diteliti pada penelitian ini terdiri dari 4 (empat) variabel. Variabel eksogen (X) terdiri dari 2 (dua) variabel, berupa kualitas pelayanan dan kualitas produk, serta variabel intervening (Y) berupa kepercayaan pelanggan dan kepuasan pelanggan sebagai variabel endogen (Z).

Metode yang digunakan dalam penelitian ini adalah metode positivistic (Puspita \& Kartika, 2019) dengan berdasarkan filsafat positivisme(Sani, Subiyakto, \& Rahman, 2018). Data yang akan digunakan berupa angka dan analysis menggunakan statistik dengan tujuan untuk menjelaskan hubungan sebab akibat yang akan diteliti.

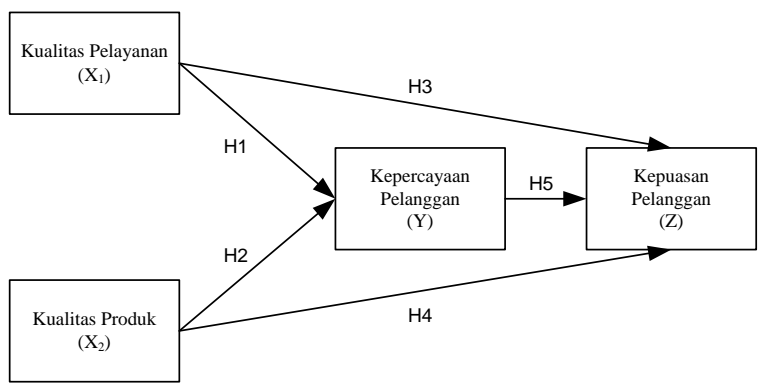

Sumber: (Husain \& Sani, 2019)

Gambar 1. Kerangka Penelitian

Menurut Gambar 1 terdapat 5 Hipotesa, yaitu : H1 : Kualitas pelayanan berpengaruh terhadap kepercayaan pelanggan pada Toko Online H2 : Kualitas Produk berpengaruh terhadap kepercayaan pelanggan pada Toko Online
H3 : Kualitas pelayanan berpengaruh terhadap kepuasan pelanggan pada Toko Online

H4 : Kualitas produk berpengaruh terhadap pelanggan pada Toko Online

H5 : Kepercayaan pelanggan berpengaruh terhadap kepuasan pelanggan

Metode yang digunakan dalam penelitian adalah dengan menggunakan metode kuantitatif(Sani \& Wiliani, 2019). Data yang digunakan berupa angka dan analisis dengan menggunakan statistik dengan tujuan menjelaskan hubungan sebab akibat antar variabel yang di teliti. Alat uji statistik yang digunakan untuk menguji hipotesis ini adalah SEM (Structural Equation Modelling) dengan menggunakan software LISREL).

Sample pada penelitian ini diambil dengan menggunakan metode non probability sampling, dengan teknik pengambilan purposive sampling(Sani, Abdul Rahman, Subiyakto, \& Wiliani, 2019). Jumlah sample dalam penelitian ditentukan berdasarkan kecukupam data untuk keperluan analisis. Karakteristik responden didasarkan pada beberapa kriteria seperti jenis kelamin, usia, tingkat pendidikan, intensitas berbelanja, intensitas penggunaan internet dalam sehari, waktu akses internet dan perangkat yang digunakan.

\section{HASIL DAN PEMBAHASAN}

Definisi operasional variabel adalah variabel penelitian dimaksudkan untuk memahami arti setiap variabel penelitian sebelum dilakukan analisis. Definisi operasional variabel juga merupakan penarikan batasan yang lebih menjelaskan ciri ciri spesifik yang lebih substantif dari suatu konsep.

Skala yang di gunakan adalah ordinal dengan instrumen pengukuran kuesioner dengan skala variabel yang akan diukur dibagi ke dalam beberapa dimensi.

Tabel 1. Variabel Dimensi dan Skala Pengukuran

\begin{tabular}{|c|c|c|c|c|}
\hline Veriabel & Dimensi & Jumlah Indikator & Skala Pengukuran & Skala \\
\hline \multirow{6}{*}{ Kualitas Pelayanan } & 1. Efficiency (Efisiensi) & 1,2 & \multirow{6}{*}{ Skala Likert } & \multirow{6}{*}{ Interval } \\
\hline & $\begin{array}{l}\text { 2. System Availability (Ketersediaan } \\
\text { Sistem) }\end{array}$ & 3,4 & & \\
\hline & 3. Tangibility (Berwujud) & 5,6 & & \\
\hline & 4. Reliability (Kehandalan) & 7,8 & & \\
\hline & 5. Responsiveness (Ketanggapan) & 9,10 & & \\
\hline & 6. Assurance (Jaminan) & 11,12 & & \\
\hline \multirow{4}{*}{ Kualitas Produk } & 1. Variety (Kelengkapan Produk) & 13,14 & \multirow{4}{*}{ Skala Likert } & \multirow{4}{*}{ Interval } \\
\hline & 2. Flexybility (Fleksibilitas) & 15,16 & & \\
\hline & $\begin{array}{l}\text { 3. Features (Ciri-ciri atau } \\
\text { Keistimewaan Tambahan) }\end{array}$ & 17,18 & & \\
\hline & $\begin{array}{l}\text { 4. Conformance to Spesification } \\
\text { (Kesesuaian dengan Spesifikasi) }\end{array}$ & 19,20 & & \\
\hline
\end{tabular}




\begin{tabular}{|c|c|c|c|c|}
\hline Veriabel & Dimensi & Jumlah Indikator & Skala Pengukuran & Skala \\
\hline & $\begin{array}{l}\text { 5. Perceived Quality (Kualitas yang } \\
\text { dipersepsikan) } \\
\text { 6. Durability (Daya Tahan) }\end{array}$ & $\begin{array}{l}21,22 \\
23,24 \\
\end{array}$ & & \\
\hline Kepercayaan Pelanggan & $\begin{array}{l}\text { 1. Trusting Belief } \\
\text { 2. Trusting Intention }\end{array}$ & $\begin{array}{c}25,26 \\
27,28,29 \\
\end{array}$ & Skala Likert & Interval \\
\hline Kepuasaan Pelanggan & $\begin{array}{ll}\text { 1. } & \text { Konfirmasi Harapan } \\
\text { (Expectation) } \\
\text { 2. Situasi Ideal (Experience) } \\
\text { 3. } \\
\text { Kepuasan General (Overall } \\
\text { Satisfaction) }\end{array}$ & $\begin{array}{l}30,31 \\
32,33 \\
34,35\end{array}$ & Skala Likert & Interval \\
\hline
\end{tabular}

Sumber: (Husain \& Sani, 2019)

\section{Uji Instrumen Data}

Uji instrumen data ini bertujuan untuk mengetahui sejauh mana kualitas instrumen penelitian yang akan digunakan. Kualitas instrumen penelitian ditentukan oleh dua kriteria utama yaitu validitas dan reliabilitas

\section{Uji Validitas Instrumen}

Uji validitas dilakukan pada setiap butir pertanyaan. Hasil $r$ hitung akan dibandingkan dengan $r$ table dimana $\mathrm{df}=\mathrm{n}-2$ dengan sig $5 \%$. Jika $r$ table $<r$ hitung, maka soal tersebut dikatajkan valid.

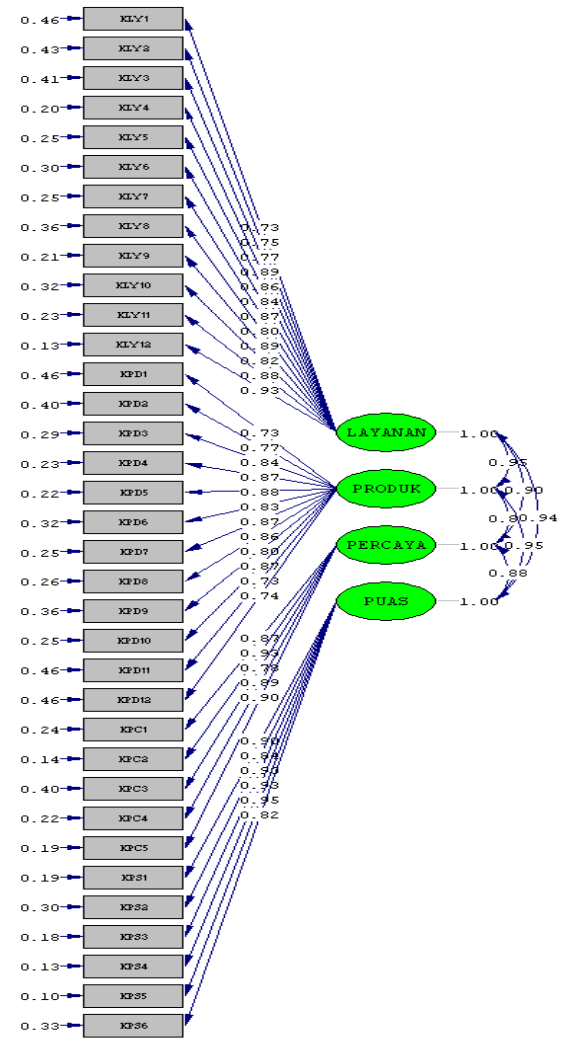

Sumber: (Husain \& Sani, 2019)

Gambar 2. Diagram Jalur Variabel

\section{Uji Reliabilitas Instrumen}

Reliabilitas dilakukan secara bersama sama terhadap seluruh butir pertanyaan, jika nilai alpha $>0,60$, maka dikatakan reliable.

Completely Standardized Solution LAMBDA-X

\begin{tabular}{|c|c|c|c|c|}
\hline & LAYANAN & PRODUK & PERCAYA & PUAS \\
\hline & ------- & -------- & -------- & ---- \\
\hline KLY1 & 0.73 & $-\quad-$ & $-\quad-$ & - \\
\hline KLY2 & 0.75 & - & $-\quad-$ & $-\quad-$ \\
\hline KLY3 & 0.77 & $-\quad-$ & $-\quad-$ & $-\quad-$ \\
\hline KLY 4 & 0.89 & - & - & $-\quad-$ \\
\hline KLY5 & 0.86 & $-\quad-$ & - & $-\quad-$ \\
\hline KLY 6 & 0.8 & - & - & - \\
\hline KLY & 0.87 & $-\quad-$ & $-\quad-$ & - \\
\hline KLY 8 & 0.80 & $-\quad-$ & $-\quad-$ & $-\quad-$ \\
\hline KLY 9 & 0.89 & $-\quad-$ & - & - \\
\hline KLY10 & 0.82 & $-\quad-$ & $-\quad-$ & - \\
\hline KLY11 & 0.88 & $-\quad-$ & - & - \\
\hline KLY1 & 20.93 & - & $-\quad-$ & $-\quad-$ \\
\hline KPD1 & - & 0.73 & - & $-\quad-$ \\
\hline KPD2 & - & 0.77 & $-\quad-$ & $-\quad-$ \\
\hline KPD3 & - & 0.84 & $-\quad-$ & - \\
\hline $\mathrm{KPD} 4$ & $-\quad-$ & 0.87 & $-\quad-$ & - \\
\hline KPD5 & $-\quad-$ & 0.88 & $-\quad-$ & $-\quad-$ \\
\hline KPD 6 & $-\quad-$ & 0.83 & - & $-\quad-$ \\
\hline KPD 7 & $-\quad-$ & 0.87 & - & - - \\
\hline KPD 8 & $-\quad-$ & 0.86 & $-\quad-$ & $-\quad-$ \\
\hline KPD9 & - & 0.80 & $-\quad-$ & - \\
\hline KPD10 & $-\quad-$ & 0.87 & - & - - \\
\hline KPD11 & - & 0.73 & $-\quad-$ & - \\
\hline KPD12 & $-\quad-$ & 0.74 & - & - - \\
\hline $\mathrm{KPC} 1$ & - & - & 0.87 & - \\
\hline $\mathrm{KPC} 2$ & - & $-\quad-$ & 0.93 & - \\
\hline KPC3 & $-\quad-$ & $-\quad-$ & 0.78 & - - \\
\hline KPC 4 & $-\quad-$ & $-\quad-$ & 0.89 & - \\
\hline KPC5 & $-\quad-$ & $-\quad-$ & 0.90 & - \\
\hline KPS1 & $-\quad-$ & $-\quad-$ & - & 0.90 \\
\hline KPS2 & - & $-\quad-$ & - & 0.84 \\
\hline KPS 3 & $-\quad-$ & - & $-\quad-$ & 0.90 \\
\hline KPS 4 & - & - & - & 0.93 \\
\hline KPS 5 & $-\quad-$ & $-\quad-$ & $-\quad-$ & 0.95 \\
\hline KPS 6 & $-\quad-$ & - & $-\quad-$ & 0.82 \\
\hline
\end{tabular}




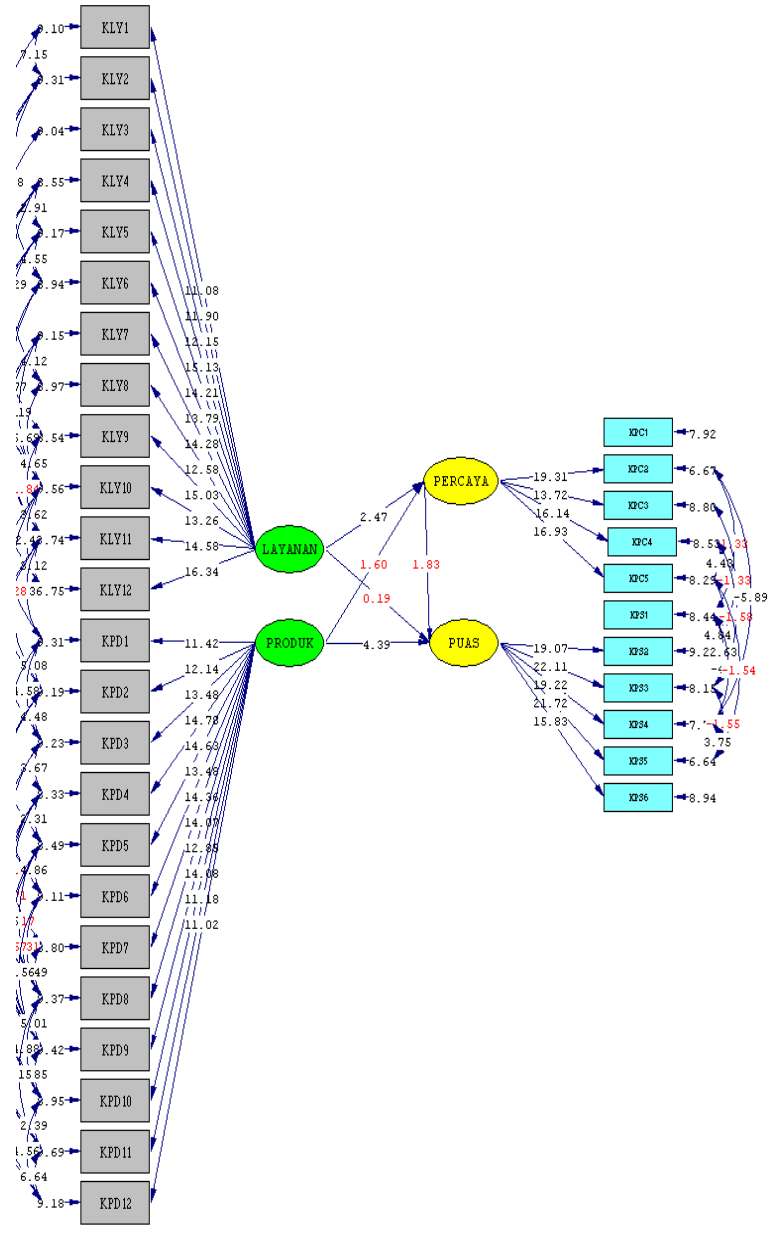

Chi-square=912.81, df=450, p-value=0.00000, RMSEA=0.07

Sumber: (Husain \& Sani, 2019)

Gambar 3. Diagram Jalur Variabel

Completely Standardized Solution LAMBDA-X

LAYANAN
------
KLY1
KLY2
KLY3
KLY4
KLY5
KLY6
KLY7
KLY8
KLY9
KLY10
KLY11
KLY12
KPD1
KPD2
KPD3
KPD4
KPD5
KPD6
KPD7
KPD8
KPD9
KPD10
KPD11
KPD12
KPC1
KPC2

$\begin{array}{cc}\text { PRODUK } & \text { PERCAYA } \\ ------ & ------ \\ 0.73 & -- \\ 0.75 & -- \\ 0.77 & -- \\ 0.89 & -- \\ 0.86 & -- \\ 0.84 & -- \\ 0.87 & -- \\ 0.80 & -- \\ 0.89 & -- \\ 0.82 & -- \\ 0.88 & -- \\ 0.93 & -- \\ -- & 0.73 \\ -- & 0.77 \\ -- & 0.84 \\ -- & 0.87 \\ -- & 0.88 \\ -- & 0.83 \\ -- & 0.87 \\ -- & 0.86 \\ -- & 0.80 \\ -- & 0.87 \\ -- & 0.73 \\ -- & 0.74 \\ -- & -- \\ -- & --\end{array}$
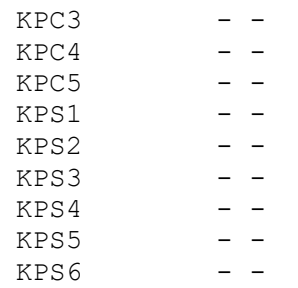

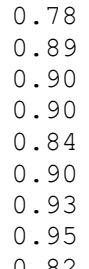

Dari penyebaran instrumen penelitian kepada pelanggan yang pernah berbelanja di toko online wilayah Jakarta yang memiliki smartphone, tablet dan laptop, sampel data yang diperoleh memiliki beberapa karakteristik.

Covariance Matrix

$\begin{array}{llllll} & \text { KPC1 } & \text { KPC2 } & \text { KPC3 } & \text { KPC4 } & \text { KPC5 } \\ & ---- & ---- & --- & --- & --- \\ \text { KPC1 } & 0.46 & & & & \\ \text { KPC2 } & 0.37 & 0.44 & & & \\ \text { KPC3 } & 0.26 & 0.28 & 0.34 & & \\ \text { KPC4 } & 0.35 & 0.38 & 0.26 & 0.47 & \\ \text { KPC5 } & 0.36 & 0.38 & 0.28 & 0.40 & 0.48 \\ \text { KPS1 } & 0.32 & 0.32 & 0.24 & 0.28 & 0.31 \\ \text { KPS2 } & 0.29 & 0.27 & 0.20 & 0.26 & 0.31 \\ \text { KPS3 } & 0.34 & 0.34 & 0.27 & 0.30 & 0.35 \\ \text { KPS4 } & 0.31 & 0.28 & 0.25 & 0.29 & 0.30 \\ \text { KPS5 } & 0.33 & 0.33 & 0.25 & 0.32 & 0.31 \\ \text { KPS6 } & 0.29 & 0.29 & 0.25 & 0.27 & 0.29 \\ \text { KLY1 } & 0.28 & 0.29 & 0.24 & 0.31 & 0.29 \\ \text { KLY2 } & 0.28 & 0.32 & 0.24 & 0.33 & 0.29 \\ \text { KLY3 } & 0.30 & 0.28 & 0.21 & 0.31 & 0.34 \\ \text { KLY4 } & 0.32 & 0.34 & 0.24 & 0.31 & 0.34 \\ \text { KLY5 } & 0.34 & 0.37 & 0.27 & 0.34 & 0.37 \\ \text { KLY6 } & 0.31 & 0.30 & 0.26 & 0.31 & 0.31 \\ \text { KLY7 } & 0.32 & 0.31 & 0.28 & 0.29 & 0.33 \\ \text { KLY8 } & 0.29 & 0.25 & 0.24 & 0.24 & 0.27 \\ \text { KLY9 } & 0.32 & 0.33 & 0.24 & 0.28 & 0.33 \\ \text { KLY10 } & 0.29 & 0.27 & 0.21 & 0.24 & 0.30 \\ \text { KLY11 } & 0.28 & 0.28 & 0.23 & 0.27 & 0.29 \\ \text { KLY12 } & 0.30 & 0.31 & 0.25 & 0.29 & 0.32 \\ \text { KPD1 } & 0.31 & 0.30 & 0.21 & 0.27 & 0.27 \\ \text { KPD2 } & 0.28 & 0.29 & 0.22 & 0.30 & 0.27 \\ \text { KPD3 } & 0.34 & 0.35 & 0.29 & 0.35 & 0.36 \\ \text { KPD4 } & 0.31 & 0.31 & 0.26 & 0.31 & 0.33 \\ \text { KPD5 } & 0.28 & 0.32 & 0.25 & 0.31 & 0.32 \\ \text { KPD6 } & 0.27 & 0.30 & 0.27 & 0.27 & 0.30 \\ \text { KPD7 } & 0.26 & 0.29 & 0.26 & 0.28 & 0.28 \\ \text { KPD8 } & 0.26 & 0.28 & 0.22 & 0.26 & 0.26 \\ \text { KPD9 } & 0.26 & 0.26 & 0.23 & 0.23 & 0.24 \\ \text { KPD10 } & 0.26 & 0.27 & 0.25 & 0.25 & 0.26 \\ \text { KPD11 } & 0.21 & 0.19 & 0.19 & 0.19 & 0.21 \\ \text { KPD12 } & 0.19 & 0.21 & 0.22 & 0.20 & 0.20 \\ & & & & & \\ & \text { Covariance Matrix } & & \\ & & & & & \\ \text { KPS2 } & \text { KPS3 } & \text { KPS4 } & \text { KPS5 } & \text { KPS6 } \\ \text { KPS2 } & 0.39 & ---- & ---- & ---- & ---- \\ \text { KPS3 } & 0.32 & 0.45 & & & \\ \text { KPS4 } & 0.30 & 0.35 & 0.39 & & \\ \text { KPS5 } & 0.31 & 0.36 & 0.38 & 0.41 & \\ \text { KPS6 } & 0.25 & 0.31 & 0.31 & 0.31 & 0.40 \\ \text { KLY1 } & 0.22 & 0.31 & 0.26 & 0.27 & 0.25 \\ \text { KLY2 } & 0.22 & 0.30 & 0.26 & 0.28 & 0.26 \\ \text { KLY3 } & 0.32 & 0.35 & 0.29 & 0.30 & 0.26 \\ \text { KLY4 } & 0.29 & 0.35 & 0.30 & 0.31 & 0.30 \\ \text { KLY } & 0.32 & 0.38 & 0.32 & 0.34 & 0.28 \\ & 0.30 & 0.31 & 0.30 & 0.30 & 0.27 \\ & & & 0.34 & 0.33 & 0.33\end{array}$




$\begin{array}{llllll}\text { KLY8 } & 0.28 & 0.32 & 0.31 & 0.31 & 0.28 \\ \text { KLY9 } & 0.29 & 0.36 & 0.30 & 0.32 & 0.28 \\ \text { KLY10 } & 0.31 & 0.35 & 0.32 & 0.32 & 0.28 \\ \text { KLY11 } & 0.28 & 0.35 & 0.30 & 0.32 & 0.25 \\ \text { KLY12 } & 0.28 & 0.33 & 0.31 & 0.32 & 0.27 \\ \text { KPD1 } & 0.27 & 0.29 & 0.26 & 0.28 & 0.25 \\ \text { KPD2 } & 0.22 & 0.26 & 0.25 & 0.26 & 0.23 \\ \text { KPD3 } & 0.31 & 0.35 & 0.33 & 0.33 & 0.29 \\ \text { KPD4 } & 0.30 & 0.34 & 0.33 & 0.33 & 0.28 \\ \text { KPD5 } & 0.28 & 0.32 & 0.31 & 0.32 & 0.28 \\ \text { KPD6 } & 0.25 & 0.30 & 0.27 & 0.27 & 0.27 \\ \text { KPD7 } & 0.27 & 0.32 & 0.32 & 0.33 & 0.27 \\ \text { KPD8 } & 0.29 & 0.30 & 0.31 & 0.34 & 0.26 \\ \text { KPD9 } & 0.26 & 0.31 & 0.27 & 0.31 & 0.24 \\ \text { KPD10 } & 0.29 & 0.32 & 0.31 & 0.33 & 0.26 \\ \text { KPD11 } & 0.25 & 0.26 & 0.30 & 0.28 & 0.24 \\ \text { KPD12 } & 0.22 & 0.28 & 0.27 & 0.27 & 0.24\end{array}$

Covariance Matrix

$\begin{array}{llllll} & \text { KLY2 } & \text { KLY3 } & \text { KLY4 } & \text { KLY5 } & \text { KLY6 } \\ \text { KLY2 } & 0.47 & --- & ---- & --- & ---- \\ \text { KLY3 } & 0.30 & 0.52 & & & \\ \text { KLY4 } & 0.32 & 0.34 & 0.42 & & \\ \text { KLY5 } & 0.34 & 0.34 & 0.38 & 0.50 & \\ \text { KLY6 } & 0.32 & 0.32 & 0.32 & 0.38 & 0.43 \\ \text { KLY7 } & 0.29 & 0.33 & 0.34 & 0.34 & 0.34 \\ \text { KLY8 } & 0.25 & 0.30 & 0.28 & 0.31 & 0.31 \\ \text { KLY9 } & 0.27 & 0.32 & 0.35 & 0.35 & 0.31 \\ \text { KLY10 } & 0.23 & 0.33 & 0.31 & 0.32 & 0.28 \\ \text { KLY11 } & 0.27 & 0.32 & 0.30 & 0.31 & 0.28 \\ \text { KLY12 } & 0.27 & 0.28 & 0.32 & 0.33 & 0.30 \\ \text { KPD1 } & 0.28 & 0.26 & 0.29 & 0.32 & 0.25 \\ \text { KPD2 } & 0.28 & 0.25 & 0.28 & 0.29 & 0.28 \\ \text { KPD3 } & 0.33 & 0.36 & 0.36 & 0.40 & 0.33 \\ \text { KPD4 } & 0.27 & 0.31 & 0.31 & 0.34 & 0.30 \\ \text { KPD5 } & 0.27 & 0.30 & 0.32 & 0.33 & 0.28 \\ \text { KPD6 } & 0.24 & 0.27 & 0.30 & 0.31 & 0.28 \\ \text { KPD7 } & 0.28 & 0.30 & 0.29 & 0.32 & 0.30 \\ \text { KPD8 } & 0.25 & 0.29 & 0.27 & 0.31 & 0.29 \\ \text { KPD9 } & 0.23 & 0.28 & 0.25 & 0.27 & 0.25 \\ \text { KPD10 } & 0.24 & 0.26 & 0.27 & 0.30 & 0.27 \\ \text { KPD11 } & 0.19 & 0.25 & 0.22 & 0.22 & 0.21 \\ \text { KPD12 } & 0.23 & 0.24 & 0.23 & 0.23 & 0.24\end{array}$

Covariance Matrix

$\begin{array}{llllll} & \text { KLY8 } & \text { KLY9 } & \text { KLY10 } & \text { KLY11 } & \text { KLY12 } \\ & ---- & ---- & ---- & ---- & -----1 \\ \text { KLY8 } & 0.45 & & & & \\ \text { KLY9 } & 0.31 & 0.44 & & & \\ \text { KLY10 } & 0.38 & 0.38 & 0.48 & & \\ \text { KLY11 } & 0.30 & 0.34 & 0.34 & 0.40 & \\ \text { KLY12 } & 0.28 & 0.33 & 0.30 & 0.32 & \\ \text { KPD1 } & 0.24 & 0.28 & 0.25 & 0.24 & 0.28 \\ \text { KPD2 } & 0.23 & 0.27 & 0.22 & 0.25 & 0.27 \\ \text { KPD3 } & 0.31 & 0.34 & 0.32 & 0.33 & 0.34 \\ \text { KPD4 } & 0.31 & 0.33 & 0.33 & 0.32 & 0.32 \\ \text { KPD5 } & 0.28 & 0.30 & 0.30 & 0.29 & 0.30 \\ \text { KPD6 } & 0.28 & 0.28 & 0.29 & 0.25 & 0.27 \\ \text { KPD7 } & 0.30 & 0.28 & 0.29 & 0.31 & 0.29 \\ \text { KPD8 } & 0.29 & 0.30 & 0.31 & 0.30 & 0.29 \\ \text { KPD9 } & 0.28 & 0.30 & 0.30 & 0.31 & 0.28 \\ \text { KPD10 } & 0.29 & 0.30 & 0.31 & 0.29 & 0.30 \\ \text { KPD11 } & 0.26 & 0.25 & 0.29 & 0.26 & 0.23 \\ \text { KPD12 } & 0.25 & 0.25 & 0.26 & 0.25 & 0.23\end{array}$

\begin{tabular}{lccccc}
\multicolumn{7}{c}{ Covariance Matrix } & & \\
& KPD2 & KPD3 & KPD4 & KPD5 & KPD6 \\
KPD2 & 0.37 & & & & \\
KPD3 & 0.34 & 0.55 & & & \\
KPD4 & 0.29 & 0.41 & 0.44 & &
\end{tabular}

\begin{tabular}{llllll} 
KPD5 & 0.27 & 0.36 & 0.34 & 0.39 & \\
KPD6 & 0.25 & 0.33 & 0.30 & 0.32 & 0.36 \\
KPD7 & 0.24 & 0.32 & 0.31 & 0.29 & 0.25 \\
KPD8 & 0.24 & 0.31 & 0.30 & 0.29 & 0.25 \\
KPD9 & 0.21 & 0.29 & 0.26 & 0.25 & 0.21 \\
KPD10 & 0.23 & 0.30 & 0.29 & 0.28 & 0.25 \\
KPD11 & 0.17 & 0.28 & 0.26 & 0.24 & 0.21 \\
KPD12 & 0.19 & 0.27 & 0.24 & 0.23 & 0.21 \\
& \multicolumn{7}{c}{ Covariance Matrix } & & \\
& & & & & \\
& KPD8 & KPD9 & KPD10 & KPD11 & KPD12 \\
KPD8 & -0.41 & ----- & ---- & ---- & ---- \\
KPD9 & 0.34 & 0.41 & & & \\
KPD10 & 0.34 & 0.35 & 0.40 & & \\
KPD11 & 0.30 & 0.28 & 0.29 & 0.42 & \\
KPD12 & 0.27 & 0.27 & 0.30 & 0.33 & 0.40
\end{tabular}

Berdasarkan hasil pengumpulan data di lapangan melalui pengumpulan jawaban kuesioner yang diperoleh dari responden yang diperoleh responden, berdasarkan jenis kelamin, tingkat pendidikan, situs belanja online yang paling sering dikunjungi, intensitas berbelanja ke toko online.

Structural Equations

PERCAYA $=0.56 *$ LAYANAN $+0.36 *$ PRODUK

ERRORVAR.$=0.17$

$\mathrm{R} 2=0.83$

$(0.23) \quad(0.22) \quad(0.028)$

$\begin{array}{lll}2.47 & 1.60 \quad 6.01\end{array}$

$\mathrm{PUAS}=0.14 * \mathrm{PERCAYA}+0.034 *$ LAYANAN $+0.81 * \mathrm{PRODUK}$ Errorvar. $=0.047$

$\mathrm{R} 2=0.90$

$\begin{array}{llll}(0.077) & (0.18) \quad(0.19) \quad(0.015)\end{array}$

$\begin{array}{llll}1.83 & 0.19 & 4.39 & 3.19\end{array}$

Reduced Form Equations

PERCAYA $=0.56 *$ LAYANAN $+0.36 *$ PRODUK,

Errorvar. $=0.17$,

$\mathrm{R}^{2}=0.83$

$(0.23) \quad(0.22)$

$2.47 \quad 1.60$

PUAS $=0.11 *$ LAYANAN $+0.87 *$ PRODUK, Errorvar.$=$ 0.050 ,

$\mathrm{R}^{2}=0.95$

$(0.18) \quad(0.19)$

$0.63 \quad 4.62$

Correlation Matrix of Independent Variables

$\begin{array}{rrc} & \text { LAYANAN } & \text { PRODUK } \\ & ------ & ----- \\ \text { LAYANAN } & 1.00 & 1.00 \\ \text { PRODUK } & 0.97 & (0.01)\end{array}$

Covariance Matrix of Latent Variables

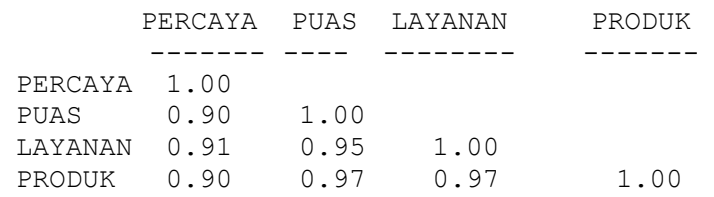




\section{KESIMPULAN}

Penelitian ini dilakukan selama dua minggu yaitu minggu pertama dan minggu kedua, dilakukan dengan menggunakan google form dan disebarkan melalui sosial media. Dari Matrix Variabel Latent terlihat bahwa cukup tinggi tingkat hubungan dari Puas terhadap layanan dan produk sebuah barang yaitu sebesar 0,97 . Hubungan yang sangat erat antara pelayanan dan kualitas barang terhadap loyalitas pelanggan, semakin tinggi peningkatan pelayanan dan kualitas barang, maka tingkat kesetiaan pelanggan makin meningkat, pelanggan akan datang dan membeli kembali ke toko online tersebut bila terjaga kualitas dan pelayanan dari pegawai.

\section{REFERENSI}

Fauzi, A., \& Harli, E. (2017). Peningkatan Kualitas Pelayanan Melalui CRM dengan Metode RAD. Jurnal RESTI (Rekayasa Sistem Dan Teknologi Informasi), 1(1), 76. https://doi.org/10.29207/resti.v1i1.16

Husain, T., \& Sani, A. (2019). Laporan Akhir Penelitian Mandiri: Kepuasan Pelanggan Toko Online Yang Dipengaruhi Kualitas Produk Dan Layanan. Jakarta.

Puspita, A., \& Kartika, C. (2019). PENGARUH EXPERIENTIAL MARKETING, CUSTOMER DELIGHT, DAN KEPERCAYAAN PELANGGAN TERHADAP NIAT PERILAKU PELANGGAN MELALUI KEPUASAN PELANGGAN SEBAGAI VARIABEL INTERVENING (Studi Kasus Pada Bengkel Resmi Yamaha PT. Roda Sakti Surya Megah). JMM17: Jurnal Ilmu Ekonomi Dan Manajemen, 6(2), 15-26. Retrieved from http://jurnal.untagsby.ac.id/index.php/jmm17/article/view/29 93

Sani, A. (2018). Penerapan Metode K-Means Clustering Pada Perusahaan. Jurnal Teknologika, 8(1).
Sani, A., Abdul Rahman, T., Subiyakto, A., \& Wiliani, N. (2019). Combining Statistical and Interpretative Analyses for Testing Readiness and IT Adoption Questionnaire. https://doi.org/10.4108/eai.27-42019.2286808

Sani, A., Subiyakto, A., \& Rahman, T. K. A. (2018). Integration of the Technology Readiness and Adoption Models for Assessing IT Use among SMEs in Indonesia, (September), 27-28.

Sani, A., \& Wiliani, N. (2019). Faktor Kesiapan Dan Adopsi Teknologi Informasi Dalam Konteks Teknologi Serta Lingkungan Pada Umkm Di Jakarta. JITK (Jurnal Ilmu Pengetahuan Dan Teknologi Komputer), 5(1), 49-56. https://doi.org/10.33480/jitk.v5i1.616

Sari, C. A. (2015). Perilaku Berbelanja Online Di Kalangan Mahasiswi Antropologi Universitas Airlangga. AntroUnairdotNet, IV(2), 205-217.

Siahaan, Y. F., Handayani, T., Pungkasanti, P. T., Wiliani, N., \& Surorejo, S. (2018). Advertising Selection in Social Media for Small and Medium Enterprises ( SMEs ) in Indonesia, (October), 0-5.

Widiyanto, I., \& Prasilowati, S. L. (2015). Perilaku pembelian melalui internet, 17(2), 109-112. https://doi.org/10.9744/jmk.17.2.109

Wiliani, N., Rahman, T., Ramli, S., \& Sani, A. (2019). Statistical Characteristics For Identification Defect of Solar Panel with Naive Bayes, 2-8. https://doi.org/10.4108/eai.27-42019.2286885

Wiliani, N., Sani, A., \& Andyanto, A. T. (2019). Klasifikasi Kerusakan Dengan Jaringan Syaraf Backpropagation Pada Permukaan Solar Panel. JITK (Jurnal Ilmu Pengetahuan Dan Teknologi Komputer), 5(1), 89-94. https://doi.org/10.33480/jitk.v5i1.662 